\title{
Determinants of Choice of Storage Systems for Root and Tuber Crops in Benue State, Nigeria
}

\author{
Okeke A.M*, Tor I.E, Iheanacho A.C
}

Department of Agribusiness, University of Agriculture, Makurdi, Nigeria.

\begin{abstract}
Determinants of Choice of Storage Systems for root and tuber crops in Benue State of Nigeria were examined. The specific objectives were to determine the factors affecting choice of storage systems by root and tuber crop farmers; and determine the relationship between choice of storage systems and farm productivity. Data were collected from 288 root and tuber crop producers in eight Local Government Areas and 32 wards, using a multi-stage sampling technique. Structured questionnaire was used to collect the data. Data collected were analysed using logit model and Mann-Whiney $U$ test. The results indicate that total output, gender, educational level, household size, and farm size significantly affect the choice of storage systems by root and tuber crop producers. The results also reveal that the output of farmers who utilized only the local storage systems exceeds those who utilized both the local storage systems in addition to the modern storage techniques. It was recommended that strategies and policies aimed at encouraging root and tuber crops farmers to adopt a particular storage technique should take into consideration their socio-economic characteristics. Also research efforts aimed at improving the effectiveness of the local storage systems using locally sourced materials should be encouraged.
\end{abstract}

Keywords - Determinants, Choice, Local Storage Systems, Root and Tuber Crops, Benue State, Nigeria.

\section{INTRODUCTION}

Root and tuber crops play significant roles in the socioeconomic lives of people of sub-Saharan Africa. Reports by African Ministerial Council on Science and Technology (AMCOST), 2006 and Food and Agricultural organization (FAO), 1998 revealed that these crops are important in household food security and income generation in many African countries. About 500 to 700 million people across the humid, tropical world which includes less-developed countries (LDCs) grow and consume these crops as their staple food (Ravi, Aked and Balagopalan, 1996).

In developing world especially Nigeria, Kana, Aliyu and Chammang (2012) reported that these root and tuber crops occupy a remarkable position in food security due to their high calorific value and carbohydrate content. They further pointed out that these crops are integral part of the food supply in the world, provide an important source of animal feed, and are also used as industrial raw materials.

In spite of the benefits of these root and tuber crops to the rural farmers in Benue State Nigeria, post-harvest losses have continued to dampen their potentiality. Oracca-Tetteh (1978) reported that though attempts have been made to increase their production by bringing more land into cultivation and use of improved seeds and chemicals, these have been less effective because any apparent gain in production has been lost to post-harvest losses.

Post-harvest losses in root and tuber crops have been attributed to the local methods for storing these crops. According to Tyler (1982); Mughogho (1989); and Omoruyi, Orhue, Ake-Obo and Akhimien (1995), produce stored under the traditional system usually do not keep long and farmers usually suffer great losses. This report is corroborated by Okoedo-Okojie and Onemolease (2009) who reported that indigenous storage of farm produce is less effective compared to modern storage methods.

Efforts gear towards addressing post-harvest losses in root and tuber crops cannot, however, be fully realized if knowledge of factors that influence root and tuber crop farmers' choice of storage systems is not known. Understanding these factors will spur innovative policy extension programme formulation towards developing the roots and tubers sub-sector in Nigeria. The broad objective of this study was to analyse the determinants of choice of storage systems for root and tuber crops in Benue State of Nigeria. The specific objectives include to:

i. determine the factors affecting choice of storage systems by root and tuber crop farmers; and

ii. determine the relationship between choice of storage systems and farm productivity. 


\section{METHODOLOGY}

Study Area

The study was conducted in Benue State, Nigeria. The State lies between latitudes $6^{0} 25^{\prime} \mathrm{N}$ and $8^{0} 8^{\prime} \mathrm{N}$ and longitudes $7^{0} 47^{\prime} \mathrm{E}$ and $10^{\circ} \mathrm{E}$. Benue State is the nation's acclaimed food basket because of the abundance of its agricultural resources. It is a major producer of food and cash crops (BNARDA, 2004). Farmers who are engaged in arable crop production like yam, cassava, sweet potato, maize, rice, vegetables, soybeans as well as livestock like poultry, goat, sheep, piggery, cattle, and fish abound. Also agribusiness entrepreneurs who are involved in yam distribution/marketing, yam chip and flour production abound in the State (Okeke, Nto and Mbanasor, 2015).

\section{Sampling Technique and Data Collection}

The population for the study consisted of root and tuber crop farmers in the State. As a result of the enormity of the population for the study, a sample of 288 root and tuber crop farmers from eight Local Government Areas and 32 wards known for root and tuber crops production were selected using multi-stage sampling technique.

The data for the study were collected using a wellstructured questionnaire. Data were collected on the socioeconomic characteristics of root and tuber crop farmers; types of local storage methods for root and tuber crop farmers; effectiveness of the various local storage methods; farm output from the various storage methods; and problems associated with the various storage methods.

\section{Data Analysis}

Logit model was used to determine the factors affecting choice of storage systems by root and tuber crop farmers, while Mann-Whiney $U$ test was used to realized the relationship between choice of storage systems and farm productivity.

\section{Model Specification}

The Logit model for determining the factors affecting choice of storage systems was specified as follows:

In $\left(\frac{P}{1-P}\right)=\mathrm{a}$

$+b_{1} X_{1}+b_{2} X_{2}+b_{3} X_{3}+b_{4} X_{4}+b_{5} X_{5}+b_{6} X_{6}+b_{7} X_{7}+b_{8} X_{8}+b_{9} X_{9}+b_{10}$

$X_{10}+\mu$ where,

In $=$ Base of natural logarithm

$\mathrm{P}=$ the probability that a respondent uses local traditional storage methods

$\mathrm{a}=$ Constant of the equation

$b_{1}-b_{10}=$ Coefficients of the predictor variables

$\mathrm{X}_{1}=$ Size of labour force (number of workers)

$\mathrm{X}_{2}=$ Annual income $(\mathrm{N})$

$\mathrm{X}_{3}=$ Output size $(\mathrm{Kg})$

$\mathrm{X}_{4}=$ Age (years)
$\mathrm{X}_{5}=$ Gender $($ male $=1 ;$ female $=0)$

$\mathrm{X}_{6}=$ Marital status $($ married $=1 ;$ single $=0)$

$\mathrm{X}_{7}=$ Membership of cooperative society $($ member $=1$; non-member $=0$ )

$\mathrm{X}_{8}=$ Educational level (years)

$\mathrm{X}_{9}=$ Household size (number)

$\mathrm{X}_{10}=$ Farm size (ha)

The Mann-Whitney model for determining the relationship between choice of storage systems and farm productivity was specified as follows:

$$
U=n_{1} n_{2}+\frac{n_{2}\left(n_{2}+1\right)}{2}-\sum_{i=m_{1}+1}^{m_{2}} R_{i}
$$

Where,

$U=$ Mann-Whitney $\mathrm{U}$ test

$\mathrm{n}_{1}=$ Sample size one (choice of storage methods)

$\mathrm{n}_{2}=$ Sample size two (farm productivity)

$R_{\mathrm{i}}=$ Rank of the sample size

\section{RESULTS AND DISCUSSION}

Factors Affecting Choice of Storage Systems

The logit model was used to investigate the effect of socioeconomic characteristics of root and tuber producers on their choice of storage systems. The estimated relationship is presented in Table 1.

From the analysis, the model chi-square was 56.04 and significant at $1 \%$, thus rejecting the null hypothesis of no difference between the model with only a constant and the model with independent variables. In other words, the existence of a relationship between the socio-economic characteristics of root and tuber producers and their choice of storage systems was supported.

The Pseudo R square was 0.3565 , indicating a relationship of $35.65 \%$ between the predictors and the predictions. In other words, about $36 \%$ of the likelihood of farmers utilizing the local storage technique is explained by the independent variables. None of the independent variables had a standard error (S.E) greater than 2.0, thus confirming the absence of numerical problem such as multicollinearity among the independent variables.

Analysis of the result shows that the coefficient of total output was significant at $5 \%$ and positively related to choice of local storage systems. The positive sign of the coefficient is at variance with the $a$ priori expectation, implying that if the output of root and tuber producers increases, the producer is $0.0000773 \%$ more likely to utilize the local storage methods. The reason is obvious. Farmers with large scale production may have challenges managing the resulting output after harvest, especially in terms of 
available space for effective storage and treatment; hence they will rely on the local methods for storing their increased output. This finding is at variance with Ansah and Teteh (2016) who reported that with large scale production, farmers are expected to make higher investments and generate larger incomes, hence such farmers are able to adopt effective postharvest management techniques.

Table.1: Logit model of the factors affecting choice of storage systems

\begin{tabular}{|c|c|c|c|c|}
\hline Variables & $\begin{array}{l}\text { Estimated } \\
\text { coefficient }\end{array}$ & Standard error & Z-value & Marginal effect \\
\hline Labour force size & -0.0384 & 0.0796 & $-0.48^{\mathrm{NS}}$ & -0.00465 \\
\hline Annual income & -0.0000000855 & 0.000000106 & $-0.81^{\mathrm{NS}}$ & -0.0000000103 \\
\hline Total output & 0.00000639 & 0.00000272 & $2.59 * *$ & $0.000000773 * *$ \\
\hline Age & -0.008396 & 0.0332 & $-0.25^{\mathrm{NS}}$ & -0.00102 \\
\hline Gender (1) & -1.2057 & 0.5755 & $-2.03 * *$ & $-0.1603 * *$ \\
\hline Marital status (1) & 0.2468 & 0.7260 & $0.34^{\mathrm{NS}}$ & 0.02958 \\
\hline $\begin{array}{l}\text { Membership of } \\
\text { cooperative (1) }\end{array}$ & 0.5158 & 0.5173 & $1.00^{\mathrm{NS}}$ & 0.06320 \\
\hline Educational level & 0.2066 & 0.0773 & $3.01 * * *$ & $0.02498 * * *$ \\
\hline Household size & 0.1043 & 0.0546 & $2.03 * *$ & $0.01261 * *$ \\
\hline Farm size & -0.5978 & 0.1821 & $-3.84 * * *$ & $-0.07228 * * *$ \\
\hline Constant & -1.4504 & 1.5913 & & \\
\hline
\end{tabular}

Log likelihood

LR Chi2 (10)

Prob $>$ Chi2
$-50.5779$

56.04

0.0000

\section{Pseudo R2}

0.3565

Source: Field survey data, 2017

*** Significant at 1\%; ** Significant at 5\%

The result shows that the coefficient of gender was significant at 5\% level and negatively related to choice of local storage systems. The negative sign of the coefficient is in agreement with the a priori expectation, implying that if a root and tuber producer is a male, he is $16.03 \%$ less likely to utilize the local storage methods. Ceteris paribus, owing to their easier accessibility to investment capital, root and tuber producers who are male are more likely to invest in improved storage techniques than their female counterpart.
This is in agreement with Okeke, Mbanasor and Nto (2015) who reported that yam entrepreneurs who are male usually have opportunity for investment capital compared to women entrepreneurs who tend to devote more of their time and earnings into their families.

Analysis of the educational level shows that the coefficient was significant at $1 \%$ level and positively related to choice of local storage systems. The positive sign of the coefficient is at variance with the a priori expectation, implying that as 
the educational level of root and tuber producers increases, they are $2.498 \%$ more likely to utilize the local storage methods. Farmers' human capital which education enhances, plays a significant role in the decision to adopt improved production and postharvest management practices. However, root and tuber producers with high level of education who still prefer the local storage techniques are those with large household size. This large household size implies that these root and tuber producers will prefer the local storage methods due to high consumption expenditure which translates to low savings and investment in improved storage techniques. This finding is corroborated by Giroh, Gal and Minampah (2012) who revealed that a farmer with a large household size will likely channel more of his/her income to food consumption expenditure rather than to save and invest in farming enterprise.

The result shows that the coefficient of household size was significant at 5\% level and positively related to choice of local storage systems. The positive sign of the coefficient is in consonance with the a priori expectation, implying that if the household size of root and tuber producer increases, the producer is $1.261 \%$ more likely to utilize the local storage methods. This is because root and tuber producers with large household sizes will invest in the cheaper local methods of storage than the expensive improved storage method as their high dependency ratio translates to more consumption expenditure, hospital bills, and school fees. This finding agrees with Okeke, Mbanasor and Nto (2015) who observed that entrepreneurs with large family size will find it difficult to save and invest owing to the high dependency ratio which translates to more consumption expenditure.
The coefficient of farm size was significant at $1 \%$ level and negatively related to choice of local storage systems. The negative sign of the coefficient is in consonance with the $a$ priori expectation, implying that if farm size of root and tuber producers increases, they are $7.228 \%$ less likely to utilize the local storage methods. Farmers with large farms are more likely to adopt improved storage techniques when compared to farmers with smaller farm size. This is because of their desire to preserve the large output from such large farms. This is corroborated by Okoedo-Okojie and Onemolease (2009) who reported that farmers with large farms are positively disposed to use of farm innovations largely because having larger farms strengthens the farmer's capacity to produce more which he/she would be interested in preserving from loss, using improve storage techniques.

\section{Relationship between Choice of Storage Systems and} Farm Productivity

The relationship between choice of storage systems and farm productivity is presented in Tables 2 and 3 .

Table 2 shows that the mean output rank of farmers who utilized both modern and traditional storage techniques was 111.37CEW while those who utilized only traditional techniques was 154.78CEW.

The test for significant difference of mean output rank between those farmers who utilized both traditional and modern storage techniques and those who utilized only traditional storage techniques is presented in Table 3.

The Man-Whitney U-test shows that there was a significant difference in the mean output rank between those farmers who utilized both modern and traditional storage techniques and those who utilized only traditional storage techniques at $1 \%$ significant level $(\mathrm{U}=4216.500, \mathrm{P}=0.000)$.

Table.2: Storage systems and farm output in cereal equivalent weights $(C E W s)^{*}$

\begin{tabular}{lll}
\hline Storage technique & Mean output rank & Sum of output ranks \\
\hline Modern and traditional technique & 111.37 & 19267.50 \\
Traditional technique & 154.78 & 11608.50 \\
\hline
\end{tabular}

Source: Field survey data, 2017

$* \mathrm{CEW}=$ Cereal Equivalent Weights: Yam $(0.26 \mathrm{CEW} / \mathrm{kg})$; Cassava $(0.32 \mathrm{CEW} / \mathrm{kg})$; Sweet potatoes $(0.28 \mathrm{CEW} / \mathrm{kg})$

Table.3: Test for significant difference of mean output rank between modern/traditional techniques and traditional techniques

\begin{tabular}{ll}
\hline Item & Farm output in Cereal Equivalent Weight \\
\hline Mann-Whitney U & $4216.500 * * *$ \\
Wilcoxon W & 19267.500 \\
Z & -4.378 \\
Asymp. Sig (2-tailed) & 0.000 \\
\hline
\end{tabular}

Source: Field survey data, 2017

Grouping variable: storage techniques; $* * *$ significant at $1 \%$ 
The low output of root and tuber producers who also utilized the modern storage techniques in addition to the local storage methods could be attributed to the high cost associated with these modern techniques. The lower cost of the traditional storage techniques in addition to their effectiveness ensure increase output. This finding is corroborated by Nwaigwe, Okafor, Asonye and Nwokocha (2015) who revealed that the advantages of these local storage methods include: the materials for construction are locally available and are at a very low cost; protect tubers from rodent attack; create favourable temperature for stored products; offers protection against weight loss owing to respiration and transpiration; does not require supplementary funds and provides protection against heat; no transport expenses involved, and keeps tubers in good condition.

\section{CONCLUSION}

The results indicate that total output, gender, educational level, household size, and farm size significantly affect the choice of storage systems by root and tuber crops producers.

The results also reveal that the output of farmers who utilized only the local storage systems exceeds those who utilized both the local storage systems in addition to the modern storage techniques.

Based on these findings, it was recommended that strategies and policies aimed at encouraging the root and tuber crops producers in adopting a particular storage technique should take into consideration those factors that influence their choice of storage systems. Also, research efforts aimed at improving the effectiveness of the already existing local storage systems using locally sourced materials should be encouraged.

\section{ACKNOWLEDGEMENT}

The authors acknowledge the financial assistance received from University Tertiary Education Trustfund (TETFund) in carrying out this study.

\section{REFERENCES}

[1] AMCOST (2006). Technologies to reduce post-harvest food loss The African Ministerial Council on Science and Technology (AMCOST) of the African Union (AU), Pretoria, South Africa, (2006). From http://www.nepadst.org/platforms/foodloss.shtml (Retrieved November 8, 2015).

[2] Ansah,I.G.K. and Tetteh, B.K.D. (2016). Determinants of Yam Postharvest Management in the Zabzugu
District of Northern Ghana. Advances in Agriculture, $1-10$.

[3] Ayegba, O. and Ikani, D.I. (2013). An Impact Assessment of Agricultural Credit on Rural Farmers in Nigeria. Research Journal of Finance and Accounting, 4(18): 80-89

[4] BNARDA (2004). The Impact of Benue State Agricultural and Rural Development Authority. Pp. 42.

[5] FAO (1998). Storage and Processing of Roots and Tubers in the Tropics. The Food and Agricultural Organisation (FAO), Rome. From <http://www.fao.org/documents/show.htm> (Retrieved November 8, 2015)

[6] Giroh, D.Y., Gal, T.N. and Minampah, C.J. (2012). Analysis of the Determinants of Savings among Gum Arabic Collectors in Selected Local Government Areas of Adamawa State, Nigeria. New York Science Journal, 5(11): 1-6

[7] Kana, H.A., Aliyu, I.A. and Chammang, H.B. (2012). Review on Neglected and Under-Utilized Root and Tuber Crops as Food Security in Achieving the Millennium Development Goals in Nigeria. Journal of Agriculture and Veterinary Sciences, Volume 4: 27-33

[8] Mughogho M.J.K.(1989). Malawi: Food security issues and challenge for 1990's. In: M Rukuni (Ed.): Food Security Policies in the SADC Region. Harare. University of Zimbabwe and Michigan State University Food Security Research in Southern Africa Project. Department of Agricultural Economics and Extension.

[9] Nwaigwe, K.N., Okafor, V.C., Asonye, G.U. and Nwokocha, J.C. (2015). Analysis of Tuber Storage Techniques in Africa: A Review. ASABE Annual International Meeting, July 26-29, New Orleans, Louisiana.

[10] Okeke, A.M., Mbanasor, J.A. and Nto, P.O. (2015). Determinants of Investment Capacity among Yam Production Entrepreneurs in Benue State, Nigeria. Journal of Poverty, Investment and Development, 16: 1-8.

[11] Okeke, A.M., Nto, P.O. and Mbanasor, J.A. (2015). Analysis of the Factors Influencing Savings and Investment Behaviour among Yam Entrepreneurs in Benue State, Nigeria. European Journal of Business and Management. 7(27): 205-209.

[12] Okoedo-Okojie and Onemolease (2009). Factors Affecting the Adoption of Yam Storage Technologies 
in the Northern Ecological Zone of Edo State, Nigeria.

J. Hum. Ecol., 27(2): 155-160

[13] Olaoye, O.J., Ashley-Dejo, S.S., Fakoya, E.O., Ikeweinwe, N.B., Alegbeleye, W.O., Asholu, F.O. and Adelaja, O.A. (2013). Assessment of Socio-economic Analysis of Fish Farming in Oyo State Nigeria. Global Journal of Science Frontier Research, Agriculture and Veterinary, 13(9): 10-18.

[14] Omoruyi, S.A., Orhue, U.X., Ake-obo, A.A. and Akhimien, C.I. (1995). Prescribed agricultural science for senior secondary schools, Benin City: Idodo Umeh Publications Limited, pp. 4-6

[15] Onemolease EA 2005. Impact of the Agricultural Development Programme (ADP) Activities in Arable Crop Production on Rural Poverty Alleviation in Edo State, Nigeria. Ph.D Thesis (Unpublished), University of Benin, Benin City, Edo State, Nigeria p123

[16] Orraca-Tetteh, R. (1978). Post-harvest physiology and storage of Nigerian crops Food and Nutrition Bulletin, 1(1). The United Nations University Press, Tokyo, Japan.. $\quad$ From <http://www.unu.edu/unupress/ food/8F011e/8F011E0a.htm> (Retrieved November 8, 2015)

[17] Ravi, V., Aked, J. and Balagopalan, C. (1996). Review on Tropical Root and Tuber Crops: Storage Methods and Quality Changes. Critical Reviews in Food Science and Nutrition, 36(7): 661-709

[18] Tyler, P.S. (1982). Misconception of food losses Food and Nutrition Bulletin 4(2), The United Nations University Press, From <http://www.unu.edu/unupress/food/8F042e/8F042E0 5.htm> (Retrieved November 8, 2015).

[19] Ufuoku, U.A., Uzokwe, U.N. and Ideh, V. (2006). Comparative Analysis of Cooperative and Noncooperative Fish Farmers in the Central Agroecological Zone of Delta State Nigeria. Extension Farming Systems Journal, 2(1): 97-104

[20] Yuguda, R.M., Girei, A.A., Dire, B., Salihu, M. (2013). Socio economic factors and constraints influencing productivity among cassava farmers in Taraba State, Nigeria. International Journal of advances in Agricultural science and technology, vol 1 pg (1-5) 